\title{
Comparative Assessment of Bacteriological Quality of Drinking Water using Membrane Filtration and Multiple Tube Fermentation Methods
}

\author{
*ADEBISI, OO; ADETOMIWA, AA; GBALA, ID \\ Section for Integrative Bioenergetics, Ecotoxicology and Environmental Systems, Department of Microbiology, Faculty of Life Sciences, \\ University of Ilorin, P.M.B. 1515, Ilorin, Nigeria \\ *Corresponding Author Email: oo.adebisi@outlook.com,soji-olusegun@unilorin.edu.ng; Tel: +234(0)8060510307
}

\begin{abstract}
Comparative assessment of 13 different drinking water sources (sachet, bottled, pipe borne and borehole) was carried using the conventional direct coliform plate count (CPC), multiple tube fermentation (MTF) and membrane filtration (MF) techniques. Physicochemical analyses indicated that the water samples meet WHO guidelines for $\mathrm{pH}$, temperature and turbidity. However, the bacteriological analyses showed that none of the drinking water source is potable according to WHO guidelines. The confirmatory and completed tests revealed the presence of faecal coliforms in some of the samples. Findings of this study demonstrate that CPC is a poor method to assess water potability while MTF and MF techniques compared relatively well. There is need to intensify effort at the monitoring of activities in the rapidly expanding packaged water industry with a view to improving the standards.
\end{abstract}

DOI: https://dx.doi.org/10.4314/jasem.v24i5.19

Copyright: Copyright $(\mathbb{C} 2020$ Adebisi et al. This is an open access article distributed under the Creative Commons Attribution License (CCL), which permits unrestricted use, distribution, and reproduction in any medium, provided the original work is properly cited.

Dates: Received: 31 March 2020; Revised: 27 April 2020; Accepted: 11 May 2020

Keywords: drinking water, membrane filtration, multiple tube fermentation, coliform

Diseases contracted from consumption of contaminated drinking water constitute a major burden on human health. The most common and widespread health risk associated with drinking water is microbial contamination. The microbiological quality of drinking water has attracted great attention worldwide because of implied public health impacts (Amira, 2011).

Total and faecal coliform have been used extensively for many years as indicators for determining the sanitary quality of water sources (Hervert et al., 2017). The enumeration of total coliform bacteria by multiple tube fermentation (MTF) and membrane filtration (MF) techniques has been used by microbiologists for many years to assess the bacteriological quality of drinking water. Various researchers (Agbabiaka and Sule, 2010; Adekunle et al., 2007; Onifade and Ilori, 2008), have analysed drinking water samples using either of the methods, but rarely compared the two for standardisation purpose.

This work was therefore, an attempt not just to investigate the bacteriological quality of drinking water sources available to residents in the University of Ilorin campus, but also to comparatively assess the sensitivity of the two techniques (MTF and MF) in enumeration of total coliform and detection of faecal coliform.

\section{MATERIALS AND METHODS}

Water samples: Permission from the school authority and consent from private water source owners were obtained before water sample collection. Water samples were collected from four (4) different sources: boreholes (3 sampling sites), pipe-borne water (4 sampling sites), sachet water (3 brands) and from bottled water ( 3 brands). Three samples were collected from each sampling site (See sample tags in Table 1). All sources were located and restricted to the permanent site of University of Ilorin, Kwara State, Nigeria. The sampling was done at intervals for 12 weeks. Temperature and $\mathrm{pH}$ of samples were measured at the site of collection or at the laboratory using a mercury-in-glass thermometer and hand-held $\mathrm{pH}$ meter. Turbidity of the water samples was determined using a spectrophotometer measured at $460 \mathrm{~nm}$ wavelength.

Microbiological analysis of water samples: Water samples were analysed immediately after collection, for the presence of total coliforms and E. coli (bacterial indicator for faecal contamination) using membrane filtration method and multiple tube fermentation method. For the multiple tube fermentation technique, a 3-3-3 regimen was used. The presumptive test was carried out using lactose broth while eosin methylene blue (EMB) agar was used for the confirmatory test. Positive result was indicated by acid and gas

*Corresponding Author Email: oo.adebisi@outlook.com,soji-olusegun@unilorin.edu.ng; Tel:

+234(0)8060510307 
production on incubation at $37{ }^{\circ} \mathrm{C}$ for $48 \mathrm{~h}$. For the membrane filtration technique, aliquots of $100 \mathrm{~mL}$ from each samples was filtered using $0.45 \mu \mathrm{m}$ paper filters. The filters were placed on EMB agar and plates were incubated at $37{ }^{\circ} \mathrm{C}$ for $24 \mathrm{~h}$. Colonies were isolated and purified then subjected to further confirmatory biochemical identification tests to screen for characters peculiar to Enterobacteriaceae.

Data analysis: Data for microbial contaminants in drinking water samples were recorded and analysed for total coliforms and E. coli. Mean and standard deviations were calculated from the results of the analysis of the three samples per sampling point. Water quality results were compared with the World Health Organisation drinking water standards. The sensitivity of each of the methods for the detection of total and thermo-tolerant coliforms was also evaluated and compared.

Table 1: Description of drinking water samples used

\begin{tabular}{l|l|l}
\hline Type & Source & Tag \\
\hline \multirow{3}{*}{ Sachet } & Unil*** & $\mathrm{A}$ \\
& KI*** & $\mathrm{B}$ \\
& Bish*** & $\mathrm{C}$ \\
\hline \multirow{3}{*}{ Bottled } & Unil*** & $\mathrm{D}$ \\
& Hab*** & $\mathrm{E}$ \\
& Vis*** & $\mathrm{F}$ \\
\hline \multirow{3}{*}{ Borehole } & New Science Lecture Theatre & $\mathrm{G}$ \\
& Senate Building & $\mathrm{H}$ \\
& Unilorin Christian Union (UCU) hostel & $\mathrm{I}$ \\
\hline \multirow{5}{*}{ Pipe-borne } & Chemistry laboratory & $\mathrm{J}$ \\
& Student hostel & $\mathrm{K}$ \\
& Ablution ground & $\mathrm{L}$ \\
& University clinic & $\mathrm{M}$ \\
\hline
\end{tabular}

***Sample names not indicated for legal or proprietary reasons

\section{RESULTS AND DISCUSSION}

The physicochemical parameters of the samples are represented in Figure 1. The sachet water samples had $\mathrm{pH}$ above 7.0 thus showing slight alkalinity while contrastingly, the bottled water ranged from 6.0-6.5, showing weak acidity. The pipe-borne and borehole waters had similar trend of almost neutral $\mathrm{pH}$ value. The variations in the $\mathrm{pH}$ could be as a result of traces of pollutants in the water samples or weather patterns (US EPA, n.d.). Although, a couple of the water samples had $\mathrm{pH}$ higher or lower than 7.0, they still fall within the EPA recommended $\mathrm{pH}$ range of 6.5-8.5. All water samples had temperature $\leq 30{ }^{\circ} \mathrm{C}$ which is within the room temperature range. The turbidity of all water samples was less than 1.5 NTU; this also conforms to the drinking water guideline of $<5$ NTU turbidity and confirms that the water samples contain minimal or no suspended particles (WHO, 2008; US EPA, n.d.).

Table 2 summarises the result of the total coliform count from the two bacteriological techniques used in this research work as well as their sensitivity in the detection of Escherichia coli, an indicator of faecal contamination. Escherichia coli was detected and isolated from five different samples with the multiple tube fermentation technique while just one sample was positive with the membrane filtration technique. Safeguarding drinking water supplies is a major health responsibility. The WHO guidelines place the greatest emphasis on the microbiological quality of drinking water. Consequently an outbreak of water borne diseases remains a great burden on the society. The bacteriological examination of drinking water is a sensitive method to assess its quality though it does not detect contamination with protozoa, virus and fungi (Manjula et al., 2011).

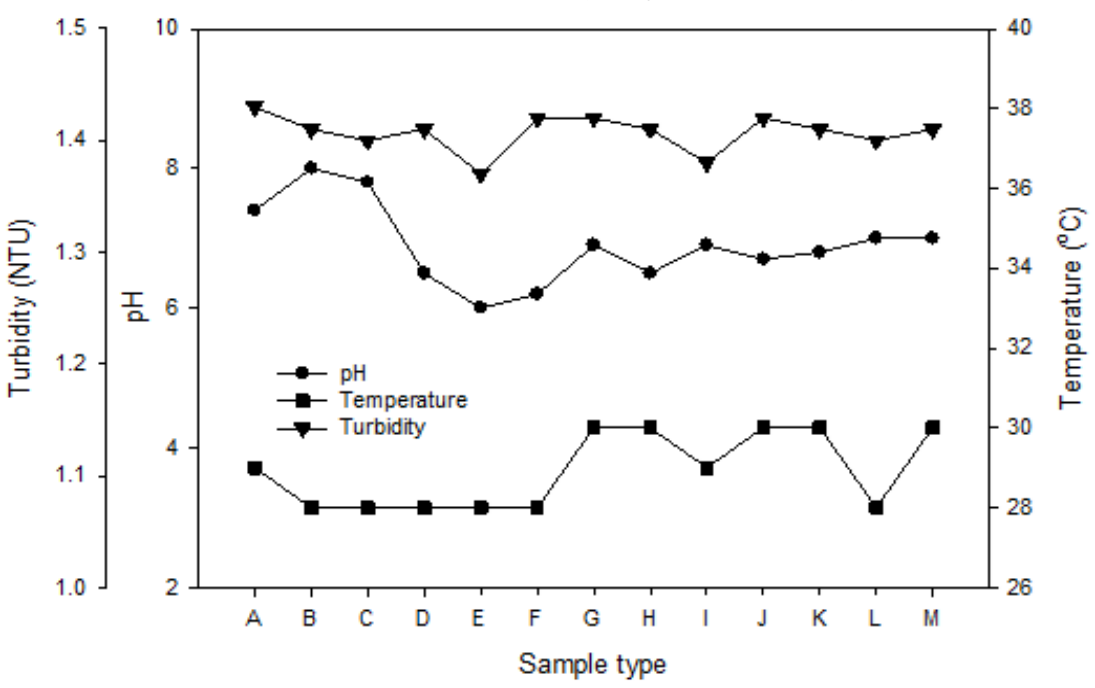

Fig. 1: Physicochemical properties of the drinking water sources 
Table 2: Assessment of water quality for total coliform using multiple tube fermentation and membrane filtration techniques

\begin{tabular}{|c|c|c|c|c|c|c|c|c|c|c|}
\hline \multirow[t]{2}{*}{ Sample } & \multicolumn{5}{|c|}{$\begin{array}{l}\text { Multiple Tube Fermentation } \\
\text { (MPN/100ml) }\end{array}$} & \multicolumn{5}{|c|}{$\begin{array}{l}\text { Membrane Filtration } \\
\text { (CFU/100ml) }\end{array}$} \\
\hline & $\mathrm{S} 1$ & $\mathrm{~S} 2$ & S3 & Mean \pm SEM & E. coli & $\mathrm{S} 1$ & S2 & S3 & Mean \pm SEM & E. coli \\
\hline A & 4 & 4 & 4 & $4 \pm 0$ & - & 208 & 266 & 150 & $208 \pm 34$ & - \\
\hline B & 23 & 4 & 4 & $10 \pm 6$ & - & 210 & NA & NA & $210 \pm 0$ & - \\
\hline $\mathrm{C}$ & 4 & 9 & 4 & $6 \pm 2$ & - & 56 & 78 & 100 & $78 \pm 13$ & - \\
\hline $\mathrm{D}$ & 4 & 11 & 93 & $36 \pm 29$ & + & 16 & 57 & 98 & $57 \pm 24$ & + \\
\hline $\mathrm{E}$ & 9 & 9 & 9 & $9 \pm 0$ & - & 216 & 249 & 180 & $215 \pm 20$ & - \\
\hline $\mathrm{F}$ & 4 & 15 & 139 & $53 \pm 43$ & - & 245 & 277 & 210 & $244 \pm 19$ & - \\
\hline G & 28 & 139 & 44 & $70 \pm 35$ & + & 255 & 228 & 279 & $254 \pm 15$ & - \\
\hline $\mathrm{H}$ & 4 & 14 & 3 & $7 \pm 3$ & - & 93 & 257 & 240 & $197 \pm 52$ & - \\
\hline I & 150 & 48 & 210 & $136 \pm 47$ & + & 160 & 228 & 296 & $228 \pm 39$ & - \\
\hline $\mathrm{J}$ & 9 & 4 & 139 & $51 \pm 44$ & - & 130 & 287 & 210 & $209 \pm 45$ & - \\
\hline $\mathrm{K}$ & 1100 & 440 & 440 & $660 \pm 220$ & + & 283 & 272 & 258 & $271 \pm 7$ & - \\
\hline $\mathrm{L}$ & 9 & 210 & 44 & $88 \pm 62$ & - & 241 & 275 & 289 & $268 \pm 14$ & - \\
\hline M & 28 & 1100 & 440 & $523 \pm 313$ & - & 265 & 243 & 242 & $250 \pm 8$ & - \\
\hline
\end{tabular}

The bottled and sachet packaged waters sold on the campus of University of Ilorin, together with the communal boreholes and the pipe-borne water exhibited variable characteristics in terms of their bacteriological quality. Results of total coliform counts using both MTF and MF techniques show the presence of total coliforms in all thirteen different drinking water sources. Using the MF technique, the mean coliform counts ranged from $57 \pm 24$ to $271 \pm 71$ CFU/100ml with sample D being the least contaminated and sample $\mathrm{K}$ the most contaminated. MTF technique however generated different, although similar result. The mean total coliform number ranged from 4 to $6.60 \times 10^{2} \mathrm{MPN} / 100 \mathrm{ml}$ with the least population in sample $\mathrm{A}$ and the highest population in sample K.

Most of the water samples did not meet the WHO drinking water guideline of 10 coliform per $100 \mathrm{ml}$ water, hence they can be said to be unfit or unsuitable for human consumption. Some of the water sources were positive for E. coli, suggestive of exposure to faecal contamination. The surveillance of areas around the boreholes and tap water sources indicated that possibility of cross contamination with sewerage pipelines. Results of total coliforms obtained in this study is similar to that of Rogbesan et al. (2002) who also obtained total coliform outside the range allowed in the WHO guidelines. The MTF technique appears to be more sensitive in terms of recovery of $E$. coli compared to the MF technique, for all sample types. This suggests that MTF technique may recover or detect low levels of $E$. coli in water than MF technique. Nicholas et al. (1986) and Mannapperuma et al. (2011) also reported the lower sensitivity of MF technique in recovering $E$. coli. Reasons suggested for this include the lower chances of survival of stressed or injured $E$. coli cells on a membrane filter surface compared to when in broth, failure to revive injured E. coli or weakened cells, or the possibility that the culture medium (EMB agar) used in the MF test is a selective medium which may be inhibitory to stressed E. coli.

Conclusion: This study revealed that the drinking water samples used did not meet the WHO guidelines for water potability (as at when the samples were collected). Hence, regular monitoring is required to enforce existing regulations and if need be, promulgate new ones. The source of water for producing packaged water (sachet or bottled) should be well monitored. The MTF technique consistently recovered more $E$. coli from a sample than the MF technique; hence more sensitive. However, MTF technique is more timeconsuming, laborious and requires lot of equipment.

\section{REFERENCES}

Adekunle, I; Adekunle, M; Gbadebo, A; Banjoko, O (2007). Assessment of groundwater quality in a typical rural settlement in Southwest Nigeria. Int. J. Environ. Res. Pub. Hea. 4(4): 307-318.

Agbabiaka, T; Sule, I (2010). Bacteriological assessment of selected borehole water samples in Ilorin metropolis. Int. J. Appl. Biol. Res. 2(2): 3137.

Amira, A; Yassir, M (2011). Bacteriological quality of drinking water in Nyala, South Darfur, Sudan. Environ. Monitor. Assess. 5(175): 37-43.

Hervert, C; Martin, N; Boor, K; Wiedmann, M (2017). Survival and detection of coliforms, Enterobacteriaceae, and gram-negative bacteria in Greek yogurt. J. Dairy Sci. 100(2): 950-960.

United States Environmental Protection Agency (US EPA). Drinking Water Regulations and Contaminants. URL: https://www.epa.gov/sdwa/ drinking-water-regulations-and-contaminants (Accessed January 20, 2020). 
Manjula, A; Shankar, G; Sharada, M (2011). Bacteriological analysis of drinking water samples. J. Biosci. Technol. 2: 220-222.

Mannapperuma, W; Herath, G; Abayasekara C; Werellagama, D; Heinonen-Tanski, H (2011). Comparison of bacteriological methods for detecting and enumerating total coliforms and Escherichia coli in water. Res. J. Microbiol. 6: 851-861.

Nicholas, J; Wanda, L; Frank, C; Therese, A; Eugene, W (1986). Comparison of membrane filter, multiple-fermentation-tube, and presenceabsence techniques for detecting total coliforms in small community water systems. Appl. Environ. Microbiol. 51(5): 1007-1012.
Onifade, A; Ilori, R (2008). Microbiological analysis of sachet water vended in Ondo State. Environ. Res. J. 2(3): 107-110.

Rogbesan, A; Eniola, K; Olayemi, A (2002). Bacteriological Examination of some Boreholes within University of Ilorin. Nig. J. Pure Appl. Sci. 9: 117-223.

WHO. (2008). Guidelines for drinking water quality: Water sampling and analysis. Geneva: World Health Organization: 2-7. 